\title{
Brain Metastasis of a Primary Testicular Pure Choriocarcinoma Presenting with Frontal Lobe Hemorrhage
}

\section{Metástase cerebral de um coriocarcinoma testicular puro primário apresentando hemorragia no lobo frontal}

\author{
Gabriel Flamarin Cavasana ${ }^{1}$ Fabricio Willian Mantelo Zanini ${ }^{2}$ Pery Prado Neto ${ }^{3}$ Rodrigo Mendonça ${ }^{4}$ \\ 1 Universidade Anhembi Morumbi, São Paulo, SP, Brazil \\ ${ }^{2}$ Neurology, Santa Casa de Misericórdia de Araçatuba, SP, Brazil \\ ${ }^{3}$ Clínica Neurologia Neurocirurgia Dr. Pery Prado Neto, \\ Jardim São Gabriel, SP, Brazil
Address for correspondence Gabriel Flamarin Cavasana, MS, Rua Ipanema, 67-Apto. 52-C, Mooca, Cep: 03164-200, São Paulo, SP, Brazil \\ (e-mail: gcavasana@hotmail.com).
}

${ }^{4}$ Neurosurgery, Santa Casa de Misericórdia de Araçatuba, SP, Brazil

Arq Bras Neurocir 2016;35:312-314.

\begin{abstract}
Keywords

- neurosurgery

- choriocarcinoma

- neoplasms

Resumo

Palavras-chave

- neurocirurgia

- coriocarcinoma

- neoplasias

We present the case of a 21-year-old male patient who was diagnosed with metastatic brain choriocarcinoma after presenting with a spontaneous cerebral hemorrhage. The treatment performed for this patient was an open surgery with full excision of the lesion. It is known that this kind of tumor is usually found in women, with low incidence in men. With this information as a baseline, we found multiple pulmonary metastases and a primary pure choriocarcinoma in his testicle.

Apresentamos o caso de um paciente do sexo masculino, de 21 anos de idade, o qual foi diagnosticado com um coriocarcinoma cerebral metastático após apresentar uma hemorragia cerebral espontânea. $\mathrm{O}$ tratamento realizado para este paciente foi uma cirurgia aberta com excisão total da lesão. Sabe-se que este tipo de tumor é normalmente encontrado em mulheres, com baixa incidência no sexo masculino. A partir desta informação, encontramos múltiplas metástases pulmonares e um coriocarcinoma primário puro em seu testículo.
\end{abstract}

\section{Introduction}

Choriocarcinoma is a gestational trophoblastic neoplasia; an aggressive malignant tumor that may present with fast hematogenous spread. ${ }^{1}$ This kind of cell tumor may develop in the testicles, however, with low incidence, accounting for only $1-2 \%$ of all malignant tumors found in men. ${ }^{2}$

This is the case of a young man, who came to our service with left hemiparesis, and a right frontal lobe hemorrhage. After diagnosed with a brain arteriovenous malformation (AVM), he underwent a craniotomy for surgical treatment. The excised lesion was compatible with choriocarcinoma. Brain metastases from germ-cell tumors (GCTs) have been reported to be rare, occurring in $\sim 4 \%$ of progressive testicular GCTs. ${ }^{3}$

\section{Case}

A 21-year-old man had a sudden episode of strong headache, which brought him to our hospital emergency room. He presented with left hemiparesis and dyslalia. He was received

June 23, 2016

accepted

October 4, 2016

published online

November 21, 2016
DOI http://dx.doi.org/

10.1055/s-0036-1595819. ISSN $0103-5355$.
Copyright (e 2016 by Thieme-Revinter

Publicações Ltda, Rio de Janeiro, Brazil
License terms

c) $(1) \$$ 
submitted to a cranial computed tomography (CT) scan that showed an acute hemorrhage in the frontal area of the right cerebral hemisphere (-Fig. 1). The local neurosurgeon decided to hospitalize the patient and perform an arteriography, once diagnosis referred to a blood vessels disease.

Arteriography showed a ring lesion in the middle cerebral artery branch that was suggestive of AVM (-Fig. 2). We decided a surgical treatment, requesting some blood exams and a chest X-ray, none showing any abnormalities.

The surgical access was a right frontal craniotomy. After the surgical access, the lesion could be clearly observed, as well as the mixture of arterial and venous blood inside of it.

The surgery was successful and the whole lesion was removed without further complications. The removed lesion was sent for pathological analysis. It was compatible, and AVM-associated, with a pure choriocarcinoma.

We requested a chest CT scan 10 days after the surgery, and this one showed multiple lesions in both lungs ( - Fig. 3). After reviewing the literature, we asked for a testicular ultrasound and quantification of the serum levels of $\beta$ human chorionic gonadotropin ( $\beta-\mathrm{HCG}$ ). The ultrasound confirmed an expansive lesion in the right testicle, ( - Fig. 4) and $\beta$-HCG blood levels were very high $(53,746.00 \mathrm{mUI} / \mathrm{mL})$. The patient was referred to the local oncology service to initiate chemotherapy.

\section{Discussion}

Choriocarcinoma is a GCT that usually affects pregnant women. Nonetheless, this kind of lesion can also appear in the testicles presenting like a mixed GCT or a pure choriocarcinoma. Testicular choriocarcinoma makes up less than $1 \%$ of the testicular GCTs when it is pure, and only 0,19\% of all testicular tumors. ${ }^{2,4}$ In the present case, we have a young patient presenting with right frontal lobe hemorrhage, which led us to ask for a cerebral arteriography. The arteriography showed a ring lesion in the

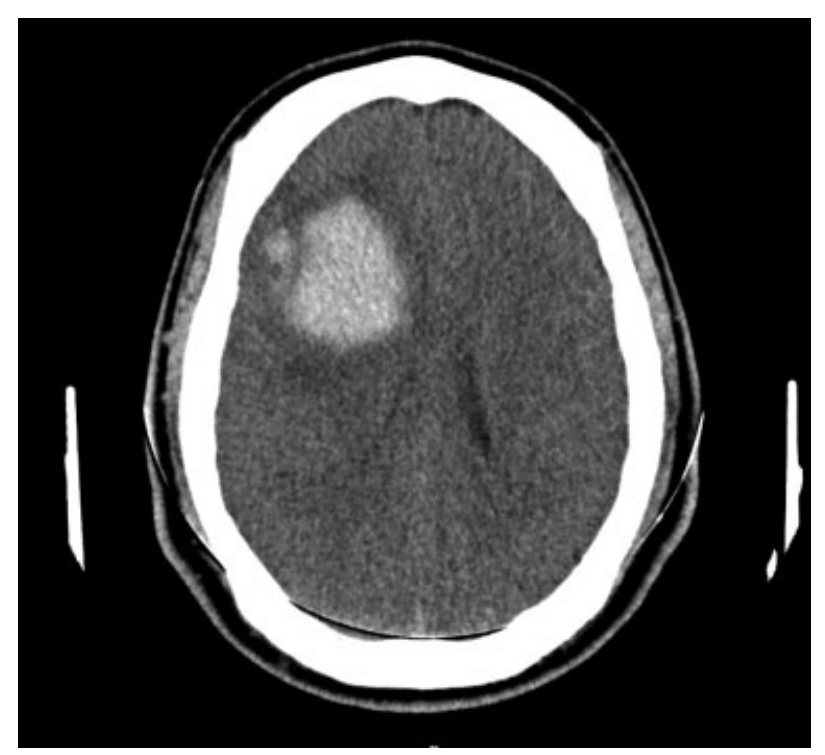

Fig. 1 Cranial CT (without contrast) showing right frontal lobe hemorrhage.

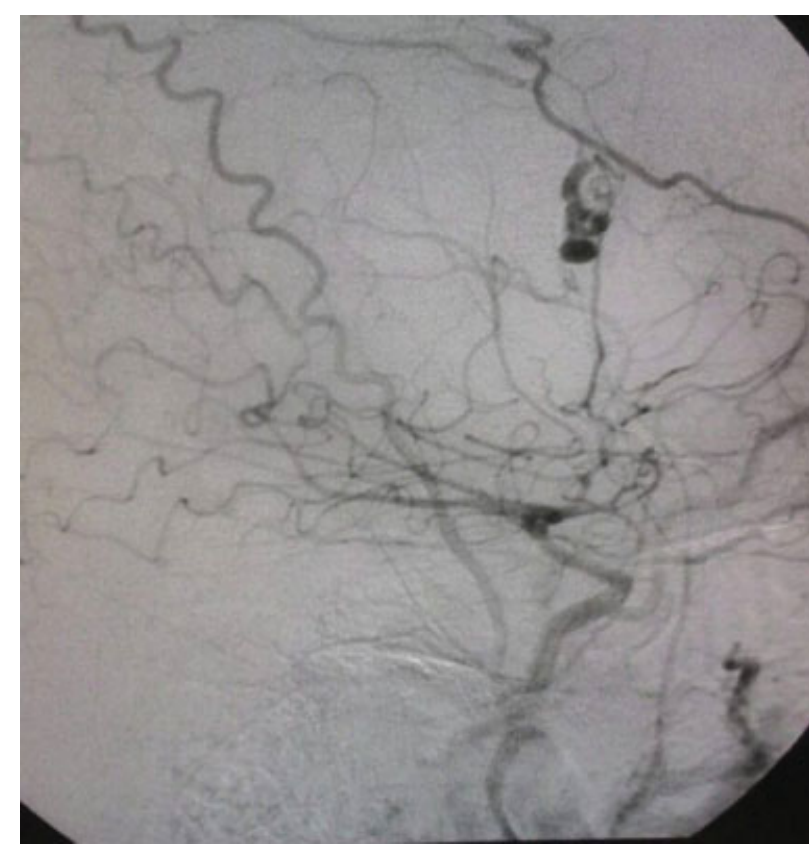

Fig. 2 Cerebral arteriography showing a ring lesion in the middle cerebral artery branch.

middle cerebral artery branch that suggested an AVM. The patient had a successful surgical excision of the lesion and presented improvement of the neurological symptoms. However, this lesion was actually a metastasis of a primary testicular choriocarcinoma. It is common to have a later diagnosis of this kind of tumor because it most commonly presents with disorders secondary to metastases, as well as hemoptysis, hematemesis, melena, epistaxis and brain hemorrhage. ${ }^{5}$

The cranial CT scan performed 30 days after the surgery showed satisfactory resolution of the case, and the patient had no more symptoms. If the removed lesion had not been sent to pathology, the tumor diagnosis would probably have been postponed. Choriocarcinoma is an aggressive tumor, but it also has a good response to chemotherapy, ${ }^{6}$ that is why it is so important to have a quick diagnosis. However, even with an early treatment, the literature suggests a poor prognosis in metastatic cases. ${ }^{4}$ After reviewing the literature,

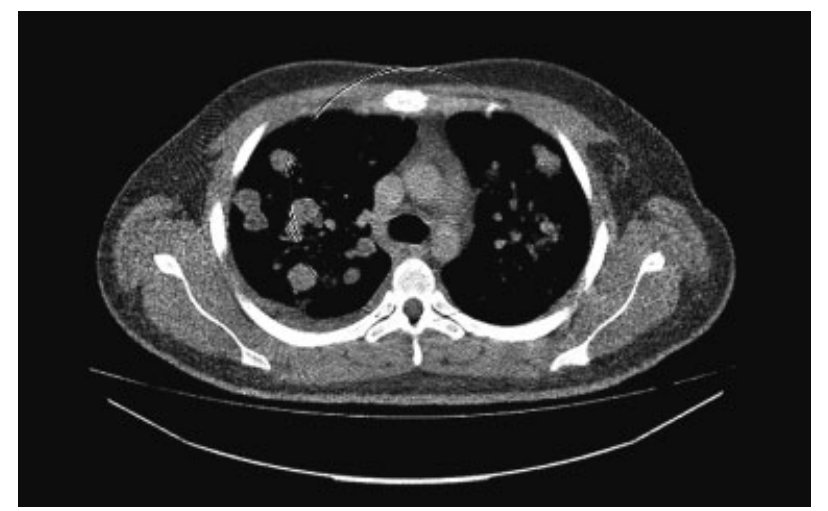

Fig. 3 Chest CT (without contrast) showing multiple metastatic lesions in both lungs. 
314 Brain Metastasis of a Primary Testicular Pure Choriocarcinoma Cavasana et al.

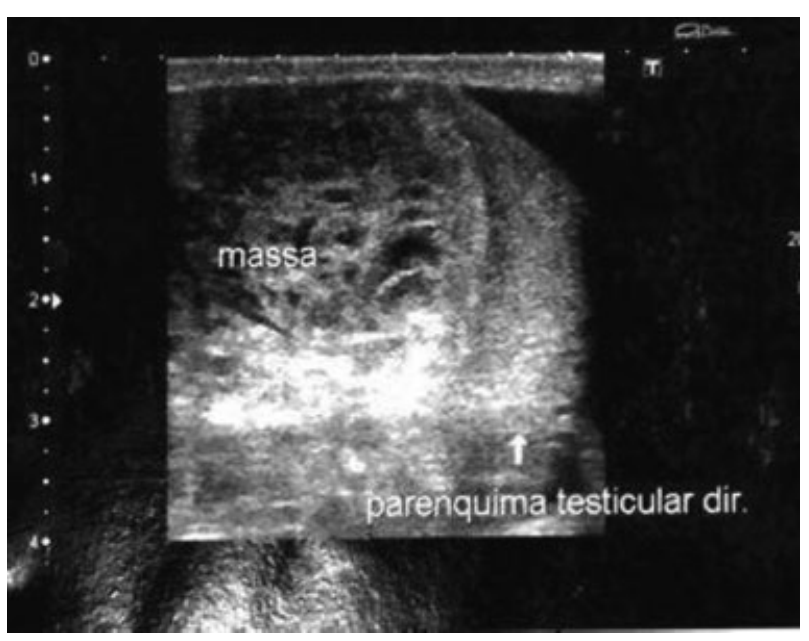

Fig. 4 Expansive mass in patient's right testicle by ultrasound exam.

we started looking for the primary lesion. In this specific case, we asked for a $\beta$-HCG, a new chest X-Ray and a testicular ultrasound, but the literature also suggests that measuring $\beta$ HCG concentrations in cerebral spinal fluid is a more sensitive and reliable indicator of tumor presence.

\section{Conclusion}

Pure testicular choriocarcinoma is one of the rarest types of trophoblastic neoplasia, a very aggressive malignant tumor that has a good response to chemotherapy, but which is usually late diagnosed because its symptoms are mostly caused by the metastatic lesions. ${ }^{8}$ Brain metastases from the germ-cells occur in $\sim 4 \%$ of progressive testicular GCTs ${ }^{3}$; and the literature suggests a poor prognostic for these cases. ${ }^{4}$ The serum levels of $\beta$-HCG can be used to support choriocar- cinoma diagnosis and treatment, once it tends to decrease after effective treatment of the primary lesion. ${ }^{6}$ In the case presented, a successful treatment for the cerebral metastasis was performed, with complete remission of the neurological symptoms.

\section{Complementary Information}

The study was conducted at the institution Santa Casa de Misericórdia de Araçatuba, Araçatuba - São Paulo, Brazil.

\section{References}

1 Chen X, Xu L, Chen X, Teng X, Zheng S. Testicular choriocarcinoma metastatic to skin and multiple organs. Two case reports and review of literature. J Cutan Pathol 2010;37(4):486-490

2 Lowe K, Paterson J, Armstrong S, Walsh S, Groome M, Mowat C. Metastatic Testicular Choriocarcinoma: A Rare Cause of Upper Gl Bleeding. ACG Case Rep J 2015;3(1):36-38

3 Pokharna P, Sharma N, Tiwari A, Devgaraha S, Mathur RM. Testicular embryonal cell carcinoma presenting as haemoptysis and skin nodules. Indian J Chest Dis Allied Sci 2014;56(2): 125-127

4 Lin D, Tan AJH, Singh-Rai R. A Literature Review and Case Report of Metastatic Pure Choriocarcinoma. Case Rep Oncol Med 2015; 2015:345018

5 Worster A, Sharma S, Mookadam F, Opie J. Acute presentation of choriocarcinoma: a case study and review of the literature. CJEM 2002;4(2):111-114

6 Li J, Yang J, Liu P, et al. Clinical characteristics and prognosis of 272 postterm choriocarcinoma patients at Peking Union Medical College Hospital: a retrospective cohort study. BMC Cancer 2016;16:347

7 Lu X, Wang C, Xu X, Jiang T. Intracerebral hemorrhage as initial presentation of nongestational choriocarcinoma: a case report and literature review. Int J Clin Exp Med 2016;9(3):6920-6925

8 Liu H, Xiao YD, Peng SP, Zhou SK, Liu J. Pituitary metastasis of choriocarcinoma: A case report. Oncol Lett 2016;11(2):1517-1520 